Acta vet. scand. $1971,12,164-184$.

From the Department of Pathology and the Department of Chemistry, National Veterinary Institute, Stockholm, Sweden.

\title{
BOVINE FLUOROSIS IN SWEDEN
}

\author{
By \\ Anna-Lisa Obel and Kurt Erne
}

Fluorosis in cattle is not uncommon in heavily industrialized areas with fluorine-containing industrial emissions. Less frequent is fluorosis of non-industrial origin (see review by Obel 1971). The present report describes some recent cases of bovine fluorosis in Sweden apparently caused by combined alimentary factors, high fluoride contents of the mineral supplement and of the drinking water.

\section{MATERIAL AND METHODS}

The post-mortem material consisted of 3 calves, 12 bull-calves, 4 heifers and 2 cows of dairy cattle of SRB breed deriving from 2 groups of farms, $\mathrm{Bs}, \mathrm{Hk}, \mathrm{Hs}$, Lö in Dalecarlia (agricultural company $\mathrm{HP}$ ), and $\mathrm{Ba}, \mathrm{Bo}$, and $\mathrm{Kp}$ in Södermanland (company $B$ ). The general conditions and the tooth status of the herds were examined on visits to some of the farms. Samples from dead and slaughtered animals were submitted for patho-anatomical and chemical examinations. Of the animals of the company HP, 1 dead calf was necropsied and head and metacarpus, and in 2 instances kidneys, of 8 slaughtered animals ( 2 calves, 4 heifers and 2 cows) were examined. Of the animals of the company B, head and metacarpus, and in 4 instances kidneys, of 12 slaughtered bull-calves were studied. Samples of water and food were secured for chemical analysis.

Samples for histological examination were fixed in $10 \%$ aqueous formaldehyde. Bone and tooth samples were decalcified in $6 \%$ nitric acid. Paraffin-embedded sections were stained with haemalum and eosin, Bock's calcium stain and PAS. 
The fluorine content was determined photometrically according to a modification of the method of Horton et al. (1952). Samples were dry-ashed, tissue and feed after the addition of calcium hydroxide, and water samples were alkalized and evaporated to dryness. The residues obtained were distilled with perchloric acid at $125-140^{\circ} \mathrm{C}$, and the fluoride in the distillate was determined by its attenuating effect on the absorbance of a thoriumarsenophenylazonaphtoldisulphonic acid (thoron) complex. The method was sensitive to about $5 \mu \mathrm{g}$ of $\mathrm{F}$ (in $50 \mathrm{ml}$ ). Fluoride added to feed samples in the range 2-10 p.p.m. (freshweight) was recovered to about $75-95 \%$, with a standard deviation of roughly $5 \%$.

\section{RESULTS}

\section{A. Farms of company $H P$}

The first cases of disease were observed in the calves at the farm HK. The cattleman did not notice any symptoms in the cows. The milk production was good, as apparently was the fertility. Occasionally, however, cows, and particularly young ones, had to be culled because of stiffness and difficulty in rising. The calves, which were bred for meat production, were not

T a b l e 1. Dental lesions in the incisors of cows of farm Hk.

\begin{tabular}{|c|c|}
\hline Cow & Lesion \\
\hline 29 & enamel defects \\
\hline 37 & dark furrows in enamel \\
\hline 57 & $川 \quad, \quad$, \\
\hline 82 & large enamel defects" \\
\hline 97 & enamel defects \\
\hline 112 & large enamel defects \\
\hline 123 & enamel defects \\
\hline 140 & , $\quad$, \\
\hline 151 & ” \\
\hline 155 & chalky flecks \\
\hline 162 & enamel defects \\
\hline 168 & , \\
\hline 177 & 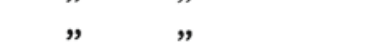 \\
\hline $\left.333^{\star}\right)$ & 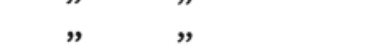 \\
\hline $\left.334^{*}\right)$ & dark furrows in enamel \\
\hline
\end{tabular}

*) heifer. 
T a ble 2. Fluorine content of water, feedstuffs and other material from farm Hk (company HP).

\begin{tabular}{lc}
\hline Material & $\begin{array}{c}\text { Fluorine } \\
\text { p.p.m. (in ash) }\end{array}$ \\
\hline Water from deep-bored well & 2.0 \\
Water from ditch in pasture & 0.2 \\
Mineral supplement I & 500 \\
Mineral supplement II & 630 \\
Thomas phosphate & 400 \\
Slag & 300 \\
Silage & 0 \\
Oil cake & $\left.90^{\star}\right)$ \\
Hay I & 30 \\
Hay II & 13 \\
\hline
\end{tabular}

*) mineral supplement probably added.

thriving and were growing slowly. They were weak and longhaired, and some deaths occurred. These symptoms appeared shortly after the drinking water supply was switched over from a ditch to a new deep-bored well. On inspection of the herd widespread enamel defects on the incisors were found in 2 bull calves (out of 10) and furrows in the enamel in 2 heifer-calves. The incisors of 48 of the 54 milk cows were examined and lesions were found in 13 cows and 2 heifers (Table 1). These findings suggested the possibility of fluorosis and, therefore, a systematic search for fluorine in the environment was initiated. The fluorine content of the well water was 2.0 p.p.m. and of the mineral supplement containing defluorinated rock-phosphate $500-600$ p.p.m. (Table 2). To the cows $150-200 \mathrm{~g}$ and to the calves $40-50 \mathrm{~g}$ of the mineral supplement was given daily. The fluorine contents of the hay and oil cake were normal. A high fluoride level was found in the thomas phosphate used as fertilizer and in the slag used for road filling. The soil of all the farms was poor in phosphate. The disease symptoms in the animals of these farms disappeared, when bone meal was substituted for the rock phosphate. One dead calf from the farm $\mathrm{Hk}$ was necropsied. The carcase was emaciated. There were extensive enamel hypoplasia in the incisival milk teeth (Fig. 1) and abrasion of the molars with hook formation (Fig. 3). The skeleton was osteoporotic (Fig. 5). Subperiosteally exostoses were seen, especially at the margin of the joints (Fig. 4). From this farm also material from 


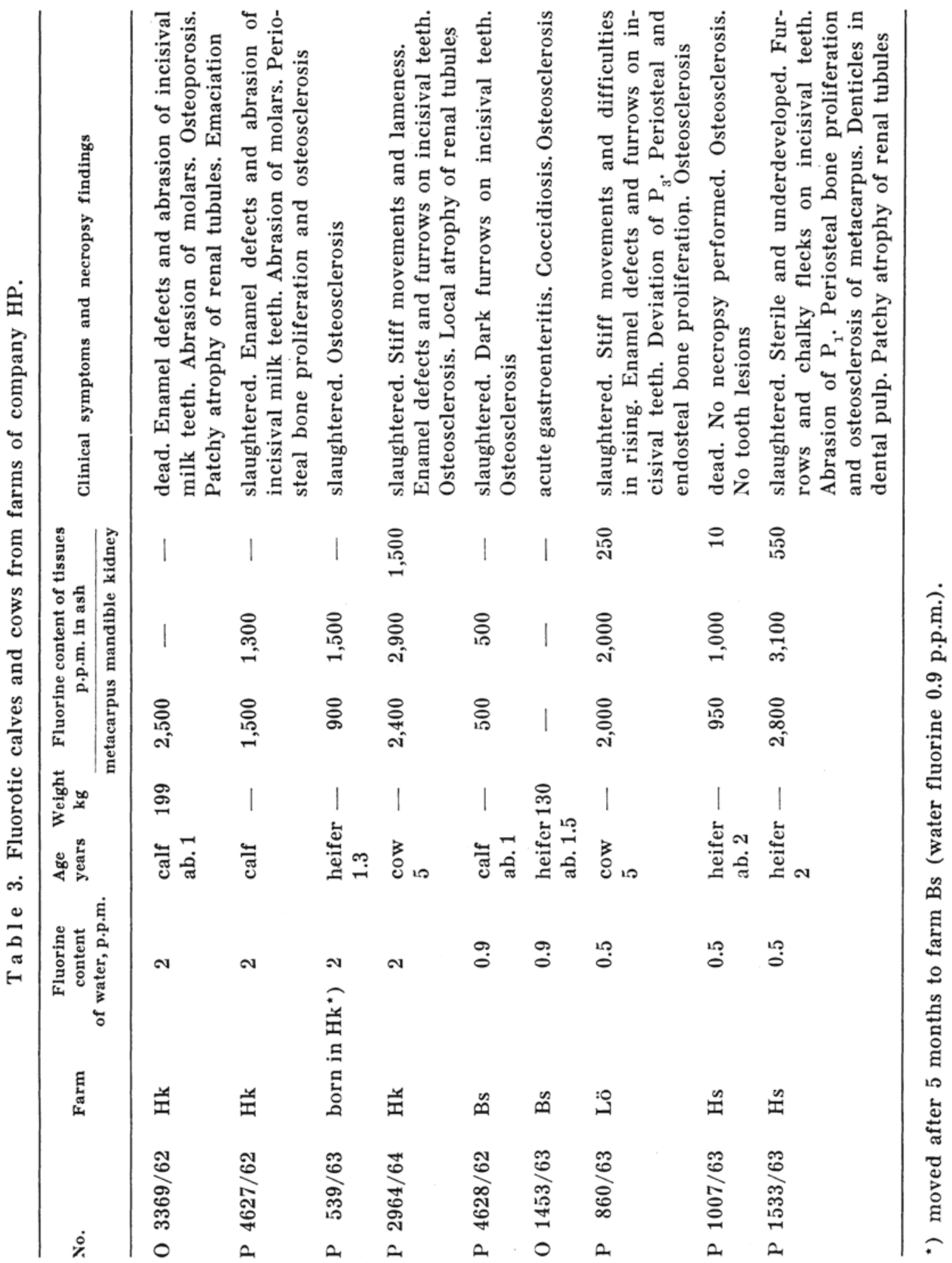


3 slaughtered animals, a calf, a heifer and a cow, was received (Table 3 ). The calf was slaughtered because of low growth rate. Numerous enamel defects were found on the incisors, and the molars were heavily abraded with hook formation. The metacarpus was osteosclerotic. The cow was lame and moved stiffly. Both in the cow and the heifer osteosclerosis was apparent.

From slaughtered animals of 4 other nearby farms of company HP material was also submitted for examination (Table 3 ). In the animals of these farms only slight symptoms were observed. Some of the heifers were sterile and underdeveloped. One cow was lame and showed difficulty in rising. Dark furrows and a few defects were observed in the incisors (Fig. 2). The drinking water at these farms contained $0.5-0.9$ p.p.m. of fluorine.

On microscopical examination the skeleton of the first dead calf (of farm Hk) proved to be the osteoporotic type (Fig. 7). The cartilage cells were heavily calcified with imperfect invading of the marrow capillaries. The cartilage protruded in tongues into the primary spongiosa. There was only insignificant bone apposition on the direction colums (Fig. 11). Furthermore, resorption of the primary spongiosa occurred in places near the cartilage border. The trabeculae of the secondary spongiosa were slender and contained cartilage in the central parts (Fig. 11). There was no remodelling of the primary spongiosa (Fig. 9) into secondary spongiosa with its thick and widely spaced trabeculae (Fig. 6). The bone marrow was oedematous and very poor in cells (Fig. 7).

The other cases were of the osteosclerotic type (Fig. 8). The epiphyseal lines of the skeleton were wide. The zone of the hypertrophic cartilage cells was enlarged and the border uneven. The penetration of the capillaries seemed to be arrested. The trabeculae of the secondary spongiosa were thick and lay close to each other (Fig. 8). They contained large amounts of central cartilage. The bone marrow was fibrillar and poor in cells (Fig. 10 ). In the compacta the Haversian canals were often very small (Fig. 13). In some places they were dilated and contained osteoid seams. The osteons were connected by less differentiated, woven bone and often surrounded by hyperchromatic lines. Accordingly, the bone locally had a mosaic appearance with irregular areas of calcification. The osteocytes were unevenly distributed and were abundant in the parts consisting of woven bone. Small resorption cavities were found locally, usually in the inner part of the compacta. The periosteum was occasionally thickened and very rich 

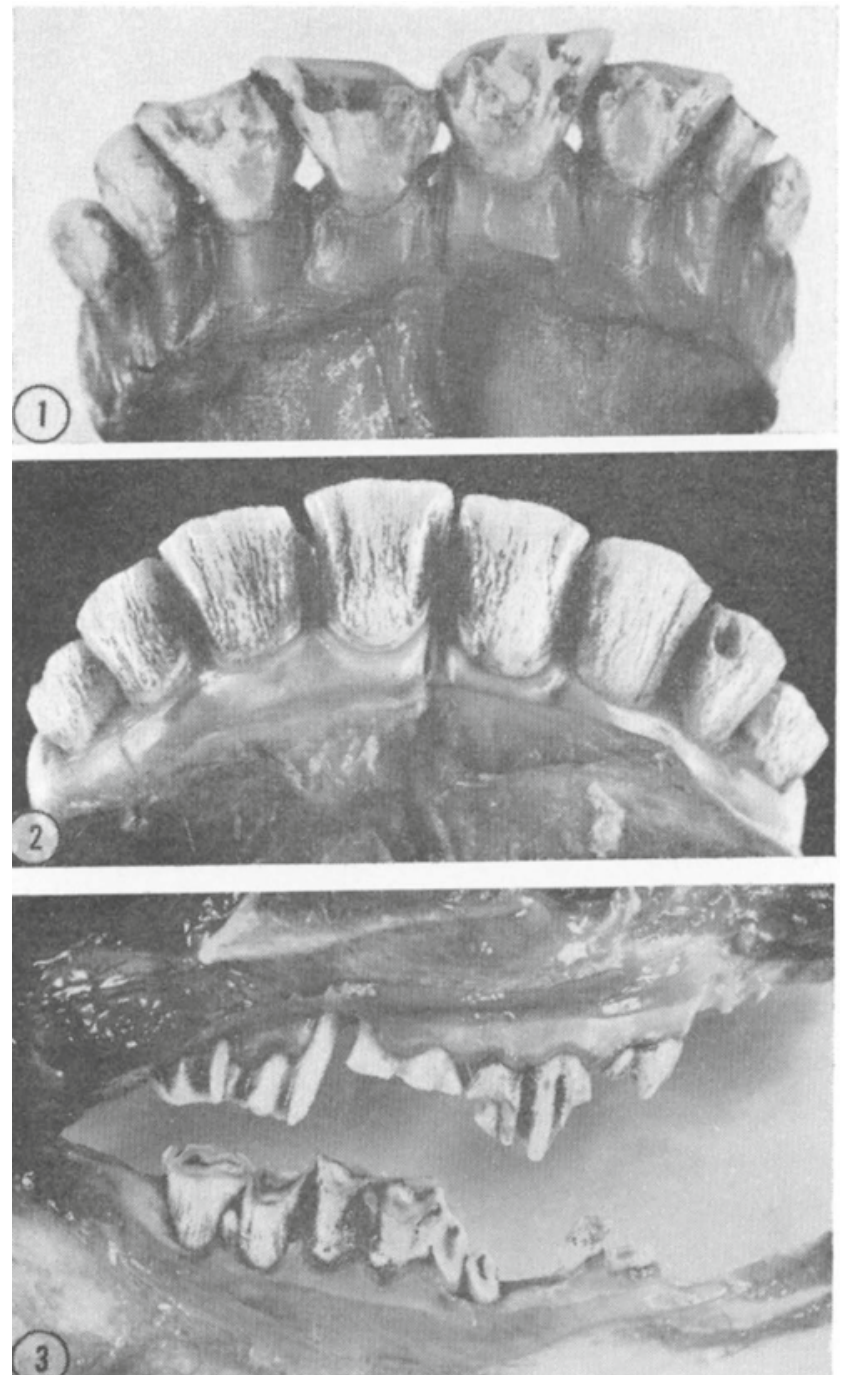

F i g u r e 1. O 3369/62. Fluorosis. Calf. Incisival milk teeth. Widespread enamel defects.

F i g u r e 2. P 860/63. Fluorosis. Cow. Permanent incisors with dark furrows. Enamel defects on left $\mathrm{I}_{3}$.

F i g u r e 3. O 3369/62. Fluorosis. Calf. Milk molars. Heavy abrasion of mandible and hook formation on $\mathrm{P}_{2}$. 

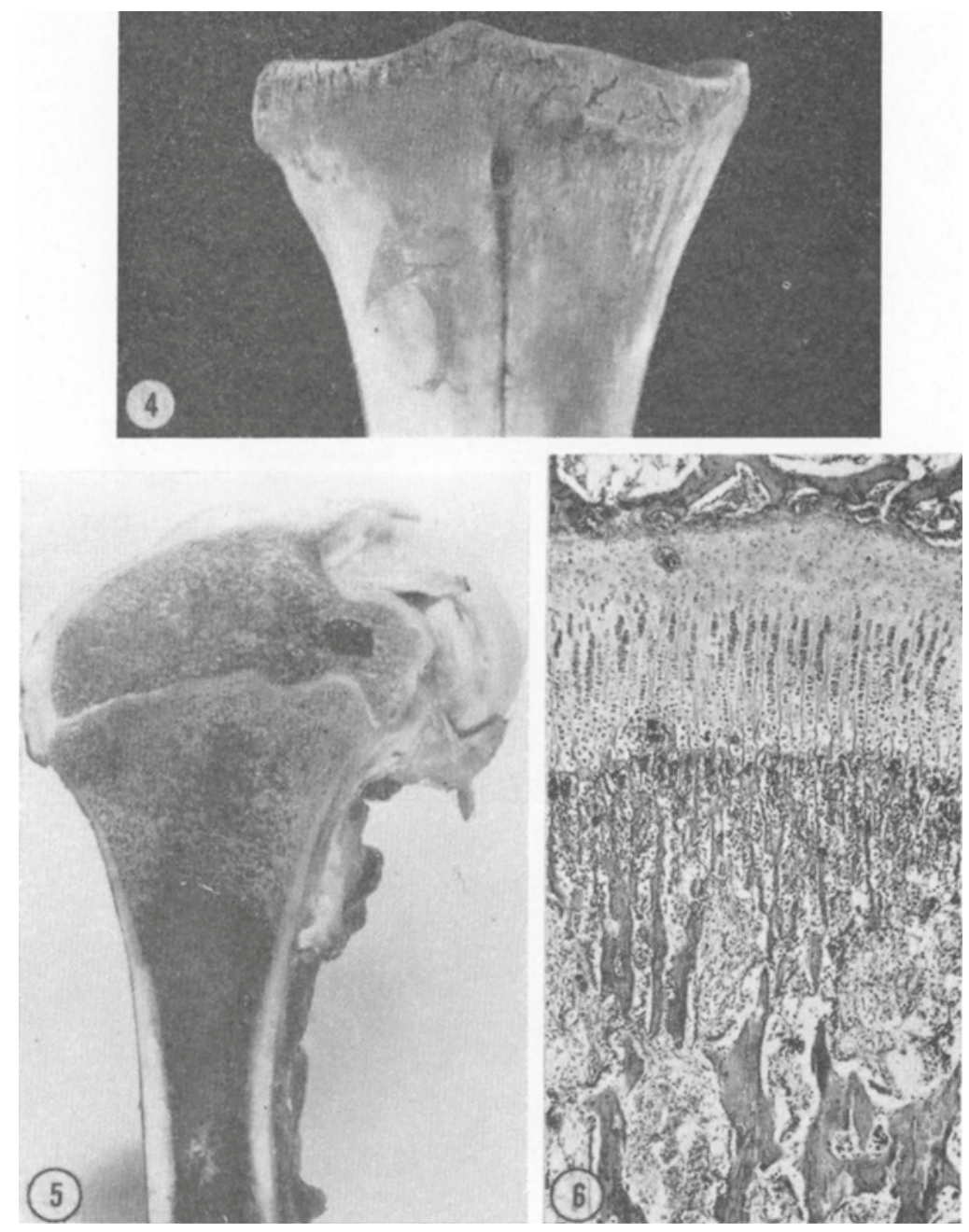

F i g u r e 4. O 3369/62. Fluorosis. Calf. Proximal end of metacarpus. Periosteal bone deposition at margin of joint.

F i g u r e 5. O 3369/62. Fluorosis. Calf. Osteoporosis.

F i g u r e 6. Normal calf. Epiphyseal cartilage. Haemalum and eosin, $\times 40$. 

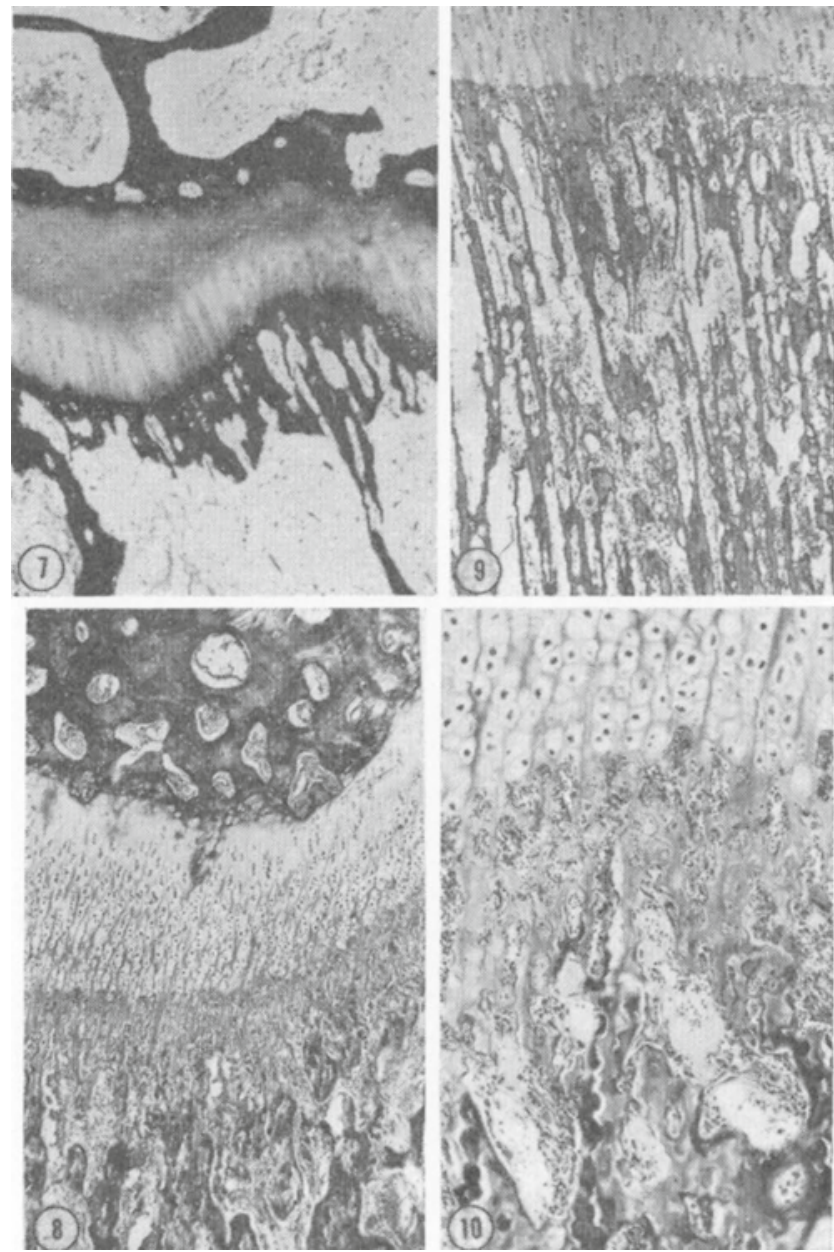

F i g u r e 7. O 3369/62. Fluorosis. Calf. Epiphyseal cartilage. Osteoporosis. Bock's calcium stain, $\times 30$.

F i g u r e 8. O 1453/63. Fluorosis. Calf. Epiphyseal line. Pronounced osteosclerosis with large trabeculae lying tight together. Haemalum and eosin, $\times 30$.

F i g u r e 9. O 3369/62. Fluorosis. Calf. Insignificant proliferation of cartilage cells, only slight development into hypertrophic cartilage cells. Trabeculae of spongiosa slender, no reorganization of primary spongiosa into normal secondary spongiosa with large trabeculae lying well apart. (Compare Fig. 6). Haemalum and eosin, $\times 30$.

F i g u r e 10 . O 1453/63. Fluorosis. Calf. Epiphyseal line. Trabeculae large and crowded and with high proportion of cartilage in centre. Haemalum and eosin, $\times 30$. 


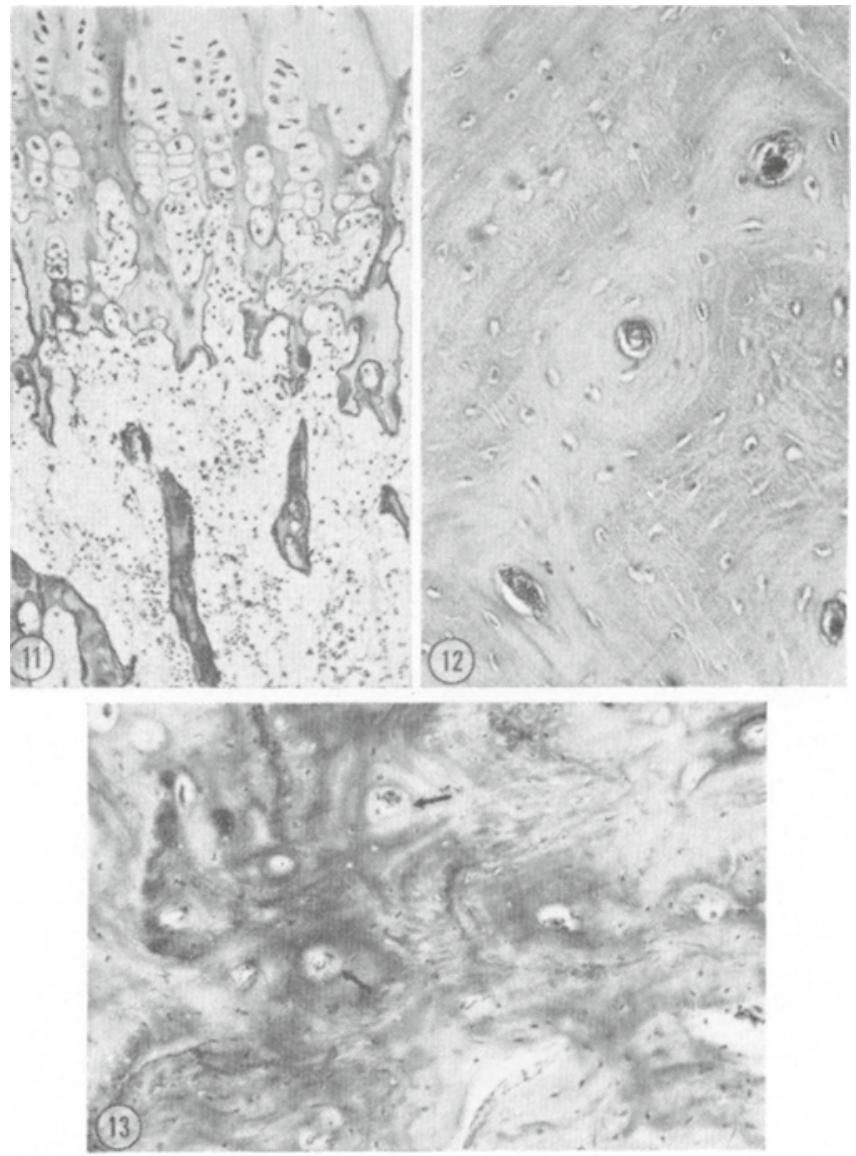

F i g u r e 11. O 3369/62. Fluorosis. Calf. Distal epiphyseal line in femur. Scanty proliferation of cartilage cells. Zone of hypertrophic cartilage cells calcified, with subnormal cell size. Very little osteoid produced on direction columns. Bone marrow poor in cells. Haemalum and eosin, $\times 90$.

F ig u re 12 . Calf. Normal compact bone. Haver's canals of equal size, evenly distributed osteocytes. Bone lamellar and calcification uniform. Haemalum and eosin, $\times 180$.

F i g u re 13. P 4627/63. Fluorosis. Calf. Mandibular cortex. Osteosclerosis with small lumen in Haver's canals. Some canals have osteoid borders. Osteons connected by immature woven bone. Calcium content highly irregular. (Compare Fig. 12). Haemalum and eosin, $\times 90$. 
in cells. In this tissue trabeculae were formed, perpendicular to the surface of the bone. They consisted of woven bone with osteoid borders (Fig. 21).

In the teeth the predentine zone was broadened and a globular calcification occurred. Small herds of imperfect calcification were often found in the dentine wall (Fig. 14). The Owen's lines were often accentuated. In 1 case a denticle was observed in the pulp (Fig. 15). In the kidneys in these cases a patchy atrophy of cortical tubules was found. These tubules, obviously belonging to single, affected nephrons, had small, shrunken cells and the basement membrane was very thick and strongly PAS-positive. In the corresponding glomeruli the capsules were also thickened (Fig. 16).

The fluorine content of the metacarpus was 2,000 and 2,400 p.p.m. (bone ash), respectively, for the 2 slaughtered cows, 900, 950 and 2,800 p.p.m. for the heifers, 500, 1,500 and 2,500 p.p.m. for the calves. The animals with the highest fluorine content of each group were those which had showed symptoms (see Table 3 ). For comparison the fluorine content was determined in the bones of a number of calves without symptoms of fluorosis, obtained from the necropsy material during 3 years (Table 4 ).

In this material the fluorine content varied between 25 and 250 p.p.m. in the bone ash.

\section{B. Farms of company $B$}

Fluorotic tooth lesions were also observed in animals of farms $\mathrm{Ba}$, and Bo. At slaughter the incisors proved to be worn to the gums. It was believed that the owner had filed them off, and he was suspected of cruelty to animals. The drinking water in $\mathrm{Ba}$ and Bo was taken from deep-bored wells with fluorine contents of 1.5 - 4.0 p.p.m., and in Kp from a small stream containing 0.1 p.p.m. of fluorine (Table 5). The heifer-calves were bred separately at Kp. They had no or insignificant tooth lesions. The bullcalves were bred at Bo with loose housing system. Except for the strong abrasion of the incisors, no symptoms were seen. The ration of the bull-calves consisted during the winter months of silage, straw, and potatoes. Mineral supplement was only given to the cows and to the calves up to 3 months of age, but it was not possible to find out the exact dose. The heifer-calves had much better food with hay and concentrate. Both groups were on pa- 

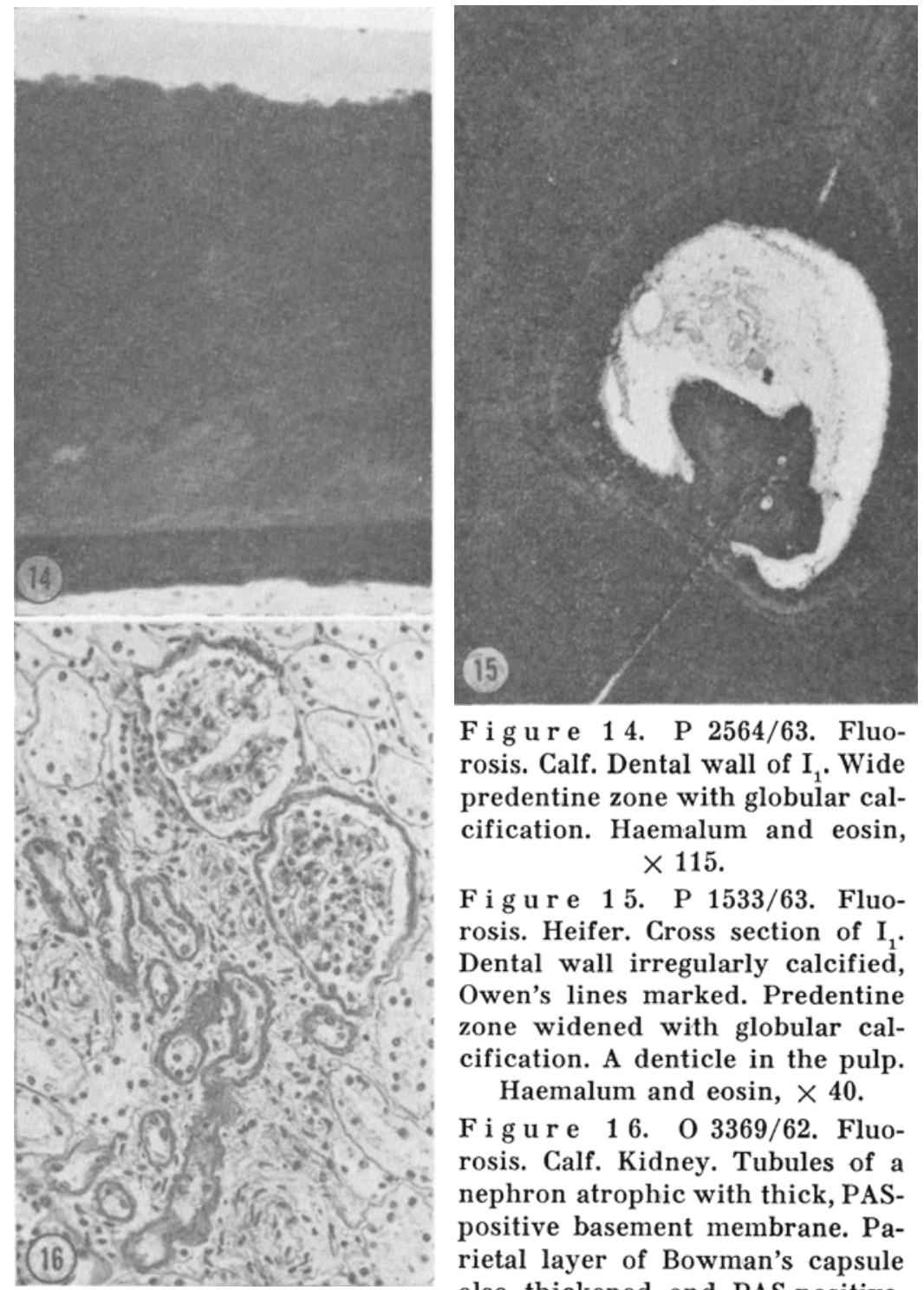

Fi g u r e 14. P 2564/63. Fluorosis. Calf. Dental wall of $I_{1}$. Wide predentine zone with globular calcification. Haemalum and eosin, $\times 115$.

Figure 15 . P 1533/63. Fluorosis. Heifer. Cross section of $I_{1}$. Dental wall irregularly calcified, Owen's lines marked. Predentine zone widened with globular calcification. A denticle in the pulp.

Haemalum and eosin, $\times 40$.

Fig u re 16 . O 3369/62. Fluorosis. Calf. Kidney. Tubules of a nephron atrophic with thick, PASpositive basement membrane. Parietal layer of Bowman's capsule also thickened and PAS-positive. PAS, $\times 225$. 
T a b le 4. Fluorine content of tissues of non-fluorotic calves in the necropsy material, received from various parts of Sweden during $1962-1965$.

\begin{tabular}{lccc}
\hline Age & Weight & \multicolumn{2}{c}{ Fluorine p.p.m. (in ash) } \\
\cline { 3 - 4 } & kg & metacarpus & mandible \\
\hline Stillborn & 25 & 30 & 25 \\
A few days & 24 & 75 & 65 \\
5 days & 29 & 60 & 60 \\
0.5 month & 45 & 50 & 130 \\
1 month & 52 & 75 & 80 \\
1 & 54 & 200 & 250 \\
3.5 months & & 200 & 150 \\
5 months & 103 & 250 & 250 \\
\hline
\end{tabular}

sture during summer. Head and metacarpus were received from 12 bull-calves (Table 6 ). In 4 cases also kidney was sent in. On macroscopical examination the incisival milk teeth in most cases were found to be worn down to the gums (Fig. 17). When part of the crown remained, enamel defects were found (Fig. 18). In some cases abnormalities in the eruption of the permanent incisors were noted with arrested eruption of single teeth (Fig. 18) or deviations (Fig. 19). The few erupted permanent incisors had dark furrows in the enamel but no enamel defects (Fig. 18).

Table 5. Fluorine content of water and feedstuffs from farms Ba. Bo and $\mathrm{Kp}$ (company B).

\begin{tabular}{lc}
\hline Material & $\begin{array}{c}\text { Fluorine } \\
\text { p.p.m. (in ash) }\end{array}$ \\
\hline Water, Ba (deep-bored well) & 1.5 \\
Water, Ba (watertrough) & 3.5 \\
Water, Bo (deep-bored well) & 4.00 \\
Water, Kp (small stream) & 0.1 \\
Silage I, Bo & 0 \\
Silage II, Bo & $50-100$ \\
Silage I, B & 1500 \\
Silage II, B & 1500 \\
Mineral supplement, Bo & 300 \\
Mineral supplement, Kp & 350 \\
Grain, Bo & $\left.60^{*}\right)$ \\
Chopped turnip, Bo & 30 \\
Rape-cake, Bo & $120^{*}$ ) \\
\hline
\end{tabular}

*) mineral supplement probably added. 
T a b l e 6. Fluorotic bull-calves from farms Ba and Bo of company B.

\begin{tabular}{|c|c|c|c|c|c|}
\hline \multirow{2}{*}{\multicolumn{2}{|c|}{ No. }} & \multicolumn{3}{|c|}{$\begin{array}{c}\text { Fluorine content of tissues } \\
\text { p.p.m. in ash }\end{array}$} & \multirow[b]{3}{*}{$\begin{array}{l}\text { enamel defects and abrasion of } \\
\text { incisival milk teeth. Dark furrows } \\
\text { on permanent } I_{1} s \text { and } I_{2} s \text {. Both } I_{1} s \\
\text { but only right } I_{2} \text { erupted }\end{array}$} \\
\hline & & \multicolumn{3}{|c|}{$\overline{\text { metacarpus mandible kidney }}$} & \\
\hline $\mathbf{P}$ & $729 / 65$ & 135 & 140 & - & \\
\hline $\mathbf{P}$ & $935 / 65$ & 190 & 220 & - & $\begin{array}{l}\text { heavy abrasion of incisival milk } \\
\text { teeth. Dark furrows on permanent } \\
\text { incisival teeth }\end{array}$ \\
\hline $\mathbf{P}$ & $936 / 65$ & 210 & 255 & - & $\begin{array}{l}\text { abrasion to gums of all incisival } \\
\text { milk teeth }\end{array}$ \\
\hline $\mathbf{P}$ & $937 / 65$ & 135 & 160 & 一 & $\begin{array}{l}\text { heavy abrasion of incisival milk } \\
\text { teeth. Dark furrows on enamel of } \\
\text { permanent } I_{1} s\end{array}$ \\
\hline $\mathbf{P}$ & $938 / 65$ & 300 & 240 & - & $\begin{array}{l}\text { heavy abrasion of incisival milk } \\
\text { teeth. Dark furrows on enamel of } \\
\text { permanent incisival teeth }\end{array}$ \\
\hline & $1022 / 65$ & 200 & 300 & 60 & $\begin{array}{l}\text { strong abrasion of } \mathrm{I}_{3} \mathrm{~s} \text { and } \mathrm{I}_{4} \mathrm{~s} \\
\text { (milk teeth). Dark furrows on en- } \\
\text { amel of permanent } \mathrm{I}_{1} \mathrm{~s} \text { and } \mathrm{I}_{2} \mathrm{~s} \text {. } \\
\text { Osteosclerosis }\end{array}$ \\
\hline & $1023 / 65$ & 270 & 140 & 55 & ” \\
\hline & $1024 / 65$ & 230 & 230 & 60 & " $\quad \quad \quad \quad \quad$ \\
\hline & $1684 / 65$ & - & 300 & - & $\begin{array}{l}\text { heavy abrasion and enamel defects } \\
\text { of incisival milk teeth. Deviation } \\
\text { of both permanent } I_{1} s\end{array}$ \\
\hline & $1685 / 65$ & - & 280 & - & abrasion of incisival milk teeth \\
\hline & $1686 / 65$ & - & 320 & 一 & 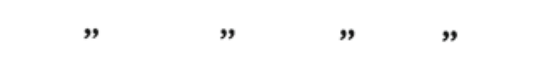 \\
\hline & $1459 / 68$ & 200 & 340 & - & $\begin{array}{l}\text { abrasion to the gums of } I_{3} s \text { and } I_{4} s \\
\text { milk teeth. Deviation of both per- } \\
\text { manent } I_{2} s \text {. Dark furrows on ena- } \\
\text { mel of permanent } I_{1} s \text { and } I_{2} s\end{array}$ \\
\hline
\end{tabular}

On microscopical examination of the mandible the compacta was found to contain osteons of normal lamellar bone. The spaces between the Haversian systems were filled with interstitial systems consisting of poorly differentiated woven bone, and the cementing lines wene pronounced (Fig. 20). The periosteum was in places broadened, and exostoses consisting of trabecular bone 


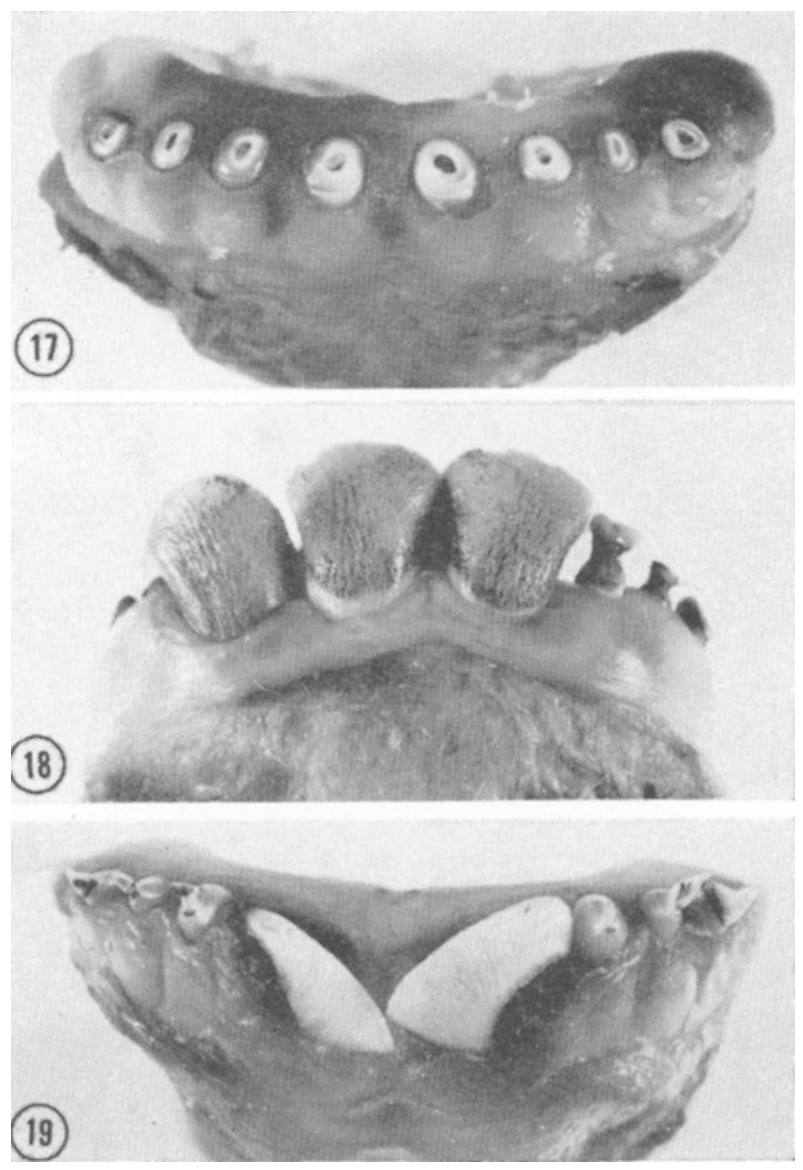

Fig u r e 1 7. P 1685/65. Fluorosis. Bull-calf. Incisival milk teeth. All incisors worn down to gums.

F i g u r e 1 8. P 729/65. Fluorosis. Bull-calf. Eruption of permanent incisors unsymmetrical. Both $\mathrm{I}_{1} \mathrm{~s}$ but only right $\mathrm{I}_{2}$ erupted. Permanent teeth have dark furrows in enamel. Milk teeth have widespread enamel defects and show strong abrasion.

F i g u r e 1 9. P 1684/65. Fluorosis. Bull-calf. Permanent $I_{1} s$ deviated on eruption, but enamel nearly normal. Milk teeth heavily worn.

occurred on the surface of the cortex. The exostoses mostly had a lamellar structure. The periosteum was poor in cells, and no active bone proliferation was observed. Between the collagenic bundles in the periosteum inactive osteocytes were found, surrounded by thin calcified capsules (Fig. 22). In the spongiosa the trabeculae were rather thick and of ten contained central cartilage. 

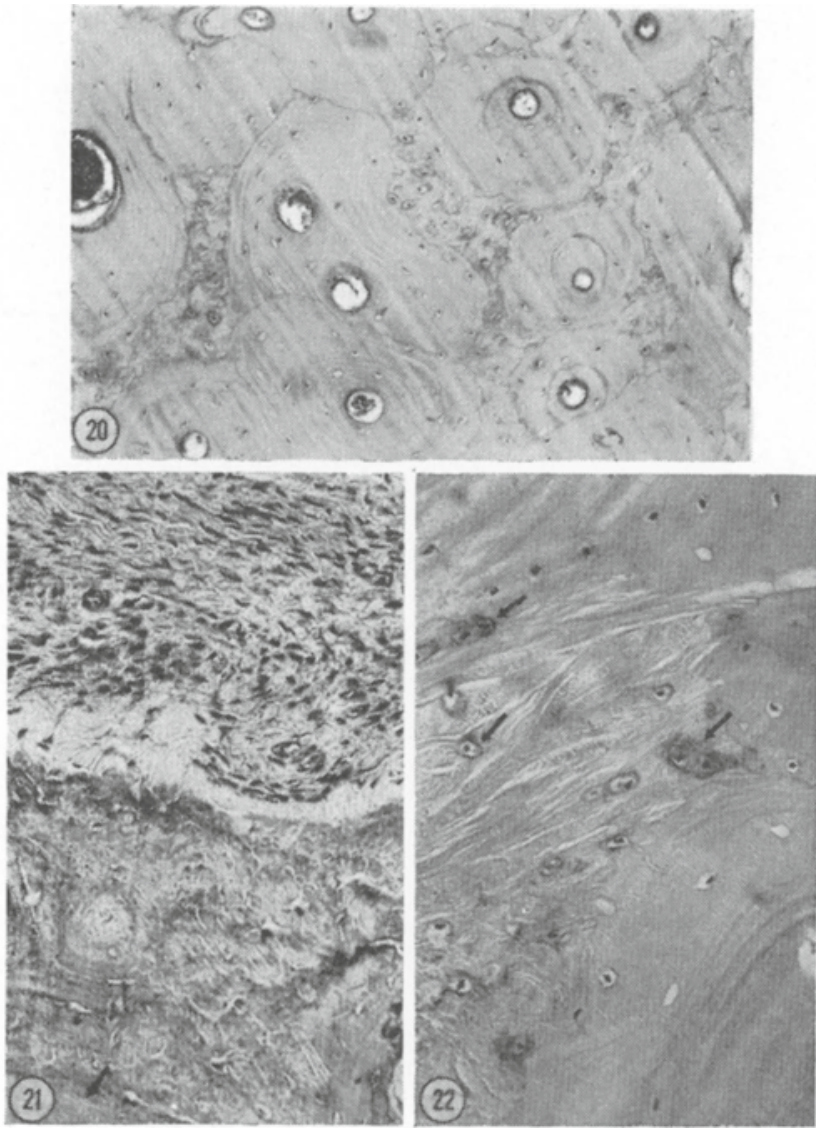

F i g u r e 20 . P 1022/63. Fluorosis in repair. Calf. Mandibular cortex. Osteons contain normal lamellar bone and are connected by immature woven bone. Haemalum and eosin, $\times 90$.

Fig u r e 21. P 4627/63. Fluorosis. Calf. Mandible. Exostosis consisting of woven bone on mandibular surface (arrow). Periosteum very dense and rich in cells. Wide osteoid seam on border of exostosis indicates active bone production. Haemalum and eosin, $\times 180$.

Fig u re 22 . P 1022/65. Fluorosis in repair. Bull-calf. Mandible. Exostosis on mandible consisting of lamellar bone and with distinct border. Periosteum poor in cells, with a few osteocytes, surrounded by thin, calcified rim (arrows). Haemalum and eosin, $\times 180$.

They contained numerous cementing lines. Tooth lesions similar to those found at the farms of the company HP were seen.

In 1 case renal lesions were found. They were rather slight but of the same type as in the animals of farms Hk. 
The fluorine content of the metacarpus of these animals ranged between 135 and 300 p.p.m. (in the ash) (Table 6).

\section{DISCUSSION}

In all the cases described here the symptoms appeared, when drinking water was taken from new deep-bored wells. The fluorine content of the water was moderately high (1.5-4.0 p.p.m.), but on the farm $\mathrm{Hk}$ and on the other farms of the company HP liberal amounts of mineral supplement were given. They consisted of defluorinated rock phosphate with a fluorine content of less than 1,000 p.p.m. which commonly is considered to be innocuous (see e.g. Snook 1962). It was not possible to obtain exact information on the quantities of the feedstuffs ingested but it could be roughly estimated that the animals in $\mathrm{Hk}$ got about equal amounts of fluorine with the drinking water and the mineral supplement. It is probable that when these 2 sources of fluorine were added together, the tolerance level was exceeded. In support of this view is the observation that the clinical symptoms disappeared, when bone meal was substituted for the defluorinated rock phosphate. The phosphate deficiency in the soil in the farms belonging to company HP may have been a predisposing factor to the lesions. Cattle are the most sensitive among domestic animals to fluoride poisoning (Phillips et al. 1955). Ezaki (1959) found that mottled teeth appeared already at drinking water with fluoride levels of $0.5-0.6$ p.p.m.

The skeleton of 1 calf was osteoporotic and of the other animals osteosclerotic. Osteoporosis is typical of cases with large fluoride intakes. On prolonged ingestion of fluoride in low doses, osteosclerosis of the skeleton will be found. Since calcium ions are more strongly bound to the fluorotic bone, an increased parathyroid activity is necessary to maintain the serum calcium level. It is now generally accepted that the bone lesions in fluorosis are induced by the parathyroid reaction (see review by Obel 1971). In our cases the subperiosteal proliferation of woven bone was common, but the areas of resorption were less pronounced.

The published reports dealing with the microscopic tooth lesions are mostly concerned with rats. There is a general agreement between the reported abnormalities. The ameloblasts are flattened and degenerated in spots with enamel hypoplasia and 
cyst formation. The dentine is imperfectly calcified and stratified by parallel lines. The odontoblasts are often enclosed in the dentine. The predentine zone is broader than normal and globular calcification is common (Phillips \& Lamb 1934, Schour \& Smith 1934, Sutro 1935, Kick et al. 1935, Huffman et al. 1942, Nozaka 1961 ). In the molar teeth the dentine may protrude into the pulp (Sutro). In those calves in the present investigation from which thin sections of the teeth were obtained, the observed changes were of the same type as the above-mentioned.

Mottled enamel of the temporary teeth is seldom reported. In man it is reported in a few cases by Smith \& Smith (1935) and Roholm (1937). Most authors state that only the permanent teeth are affected in bovines, and lesions of the temporary teeth are not described in calves. The cause of the pronounced lesions in the calves described here is unknown.

Both acute and chronic fluorine intoxications are known to cause lesions in the kidneys of rats. In acute cases, Ogilvie (1953) found degenerative changes in the collecting tubules with oedema in the renal papillae, and Taylor et al. (1961) observed necroses in the tubules of the inner third of the cortex. Simon \& LottStoltz (1967) found necrosis of the ascending limb of Henle's loop in rats acutely poisoned by fluoride. In chronic poisoning, Phillips \& Lamb observed a parenchymatous degeneration of the convoluted tubules in rats and occasionally hyaline degeneration in the blood vessels. Macroscopically the kidneys had a spotted appearance. In experiments lasting for 24 and 48 weeks, Bond \& Murray (1952) observed the kidneys to become dark, shrunken and nodulated. The basement membrane of Bowman's capsule was thickened, and the glomeruli were shrunken with thickened capillaries. In the tubules degenerative changes were found, finally leading to interstitial fibrosis. In domestic animals renal lesions were mainly found in pigs. Pigs are more resistant than bovines against fluorosis, and this is supposed to be connected with a greater ability to excrete fluoride renally. In experiments with pigs Kick et al. found the kidneys to be pale, firm and with numerous contractions on the surface. On histological examination a destruction of the convoluted tubular epithelium and a marked infiltration of fibrous tissue throughout the organ were found.

Kidney lesions have not been reported in bovine fluorosis. However, the lesions observed in our cases are of the same type 
as those described for rats and swine. The fluorine content of the metacarpal bones of the animals of the farm $\mathrm{Hk}$ and of the other farms of the company HP was lower than is usually recorded in cases of fluorosis. For the calves bone ash fluorine levels ranged between 500 and 2,400 p.p.m. and for the heifers and cows between 900 and 2,800 p.p.m. Maplesden et al. (1958) state that skeleton lesions do not occur until at fluorine levels above 4,000 p.p.m., in dry, fat-free bone. Suttie et al. (1958) considered a fluorine level below 4,500 p.p.m., in dry, fat-free bone, to be innocuous, and Shupe (1960) suggested the borderline level to be 4,000 p.p.m., in dry, fat-free bone. However, several reports suggest that there is no correlation between the degree of fluorotic lesions and the fluorine content of the bone. In the bull-calves of the farm Bo no other symptoms than the strong wear of the temporary incisors were noticed. This finding was at first thought to be of little significance. In these cases the fluorine content of the skeleton was normal. Therefore, it might be suspected that the observed tooth lesions were of another aetiology. However, the fluorine content of the water at 2 of the farms, where the calves were born, was 1.5 and 4.0 p.p.m., respectively, and the cows were given conventional doses of rock phosphate containing $500-600$ p.p.m. of $\mathrm{F}$ as a mineral supplement.

The fluorine content of the ration of the bull-calves during the fattening period was rather low as they did not get any mineral supplement. Presumably they were born with an elevated fluorine content in the skeleton and a consequent inferior quality of their temporary incisors with a reduced resistance to wear. Subsequently most of the fluorine of the skeleton might have been excreted by the kidneys. The microscopic skeletal lesions with normal lamellar bone facing the Haversian canals and an inactive stage of the subperiosteal bone proliferation are suggestive of an previous fluoride intoxication now being in repair.

\section{REFERENCES}

Bond, A. M. \& M. M. Murray: Kidney function and structure in chronic fluorosis. Brit. J. exp. Path. 1952, 33, 168-176.

Burns, K. N., M. Gitter \& M. D. Keeling: Fluorosis of non-industrial origin in a dairy herd. Vet. Rec. 1962, 74, 860 -861 .

Ezaki, Y.: Studies on enzootic fluorosis in cattle with special reference to mottled teeth. J. Japan. vet. med. Ass. 1959, 12, 383-388. 
Horton, A. D., P. F. Thomason \& F. J. Miller: Spectrophotometric determination of inorganic fluoride. Analyt. Chem. 1952, 2/, $548-550$.

Huffman, M. M., C. Schuck \& W. J. Furuta: Histologic study on the effects of fluorine administered in dry and moist diets on teeth of young albino rats. J. dent. Res. 1942, 21, 157-170.

Kick, C. H., R. M. Bethke, B. H. Edgington, O. H. Wilder, P. R. Record, $W$. Wilder, T. J. Hill \& $S$. W. Chase: Fluorine in an animal nutrition. Ohio agric. exp. Sta. Bull. 558, 1935.

Maplesden, D. C., I. Motzok, W. T. Oliver \& H. D. Branion: Fluorosis review and field observations. Canad. J. comp. Med. 1958, 22, 427-432.

Nozaka, K.: Experimental study on fluorine poisoning. Acta path. jap. $1961,11,65-85$.

Obel, A.-L.: A literary review on bovine fluorosis. Acta vet. scand. $1971,12,151-163$.

Ogilvie, A. L.: Histologic findings in the kidney, liver, pancreas, adrenal, and thyroid glands of the rat following sodium fluoride administration. J. dent. Res. 1953, 32, 386-397.

Phillips, P. H. \& A. R. Lamb: Histology of certain organs and teeth in chronic toxicosis due to fluorine. Arch. Path. 1934, 17, 169176.

Phillips, P. H., D. A. Greenwood, C. S. Hobbs \& C. F. Huffman: The fluorosis problem in livestock production. Nat. Acad. Sci., Nat. Res. Counc. 1955, Publ. 381.

Roholm, K.: Fluorine intoxication. Thesis. Copenhagen 1937, 364 pp.

Schour, I. \& M. C. Smith: The histologic changes in the enamel and dentine of the rat incisor in acute and chronic experimental fluorosis. Univ. Arizona, agric. exp. Sta. Techn. Bull. No. 52, 1934.

Shupe, J. A.: The chemistry, histology, and roentgenology of the teeth and bones of large animals. A.M.A. Arch. industr. Hith 1960, 21, $346-347$.

Simon, G. \& Lott-Stoltz: Nierenveränderungen bei Ratten zufolge NaFVergiftung. (Kidney lesions in fluoride poisoned rats). Schweiz. Arch. Tierheilk. 1967, 109, 53-57.

Smith, M. C. \& H. V. Smith: Mottled enamel of deciduous teeth. Science $1935,81,77$.

Snook, L. C.: Rock phosphate in stock feeds. The fluorine hazard. Aust. vet. J. 1962, 38, 42-47.

Sutro, C. J.: Changes in the teeth bone in chronic fluoride poisoning. Arch. Path. 1935, 19, 160-173.

Suttie, J. W., P. H. Phillips \& R. F. Miller: Studies on the effects of dietary sodium fluoride on dairy cows. III. Skeletal and soft tissue fluorine deposition and fluorine toxicosis. J. Nutr. 1958, $65,293-304$.

Taylor, J. M., J. K. Scott, E. A. Maynard, F. A. Smith \& H. C. Hodge: Toxic effects of fluoride on the rat kidney. I. Acute injury from single large doses. Toxicol. appl. Pharmacol. 1961, 3, 278-289. 


\section{SUMMARY}

Fluorotic lesions have been studied in cows and calves of SRB breed on farms belonging to 2 agricultural companies. From the one company (HP) in Dalecarlia 3 calves, 4 heifers and 2 cows were examined and from the other (B) in Södermanland 12 bull-calves. The submitted material consisted of a carcase from 1 dead calf and skull, metacarpus and in some cases kidneys from slaughtered animals. The fluorine content of feed and water samples was determined. In material from HP extensive enamel defects and strong wear were found in the deciduous incisors. Fluorotic lesions in calves have not been described previously. One calf had strong osteoporosis and in the rest of the material osteosclerosis and subperiosteal bone apposition was found. In the kidneys some tubular atrophy was found. Kidney lesions have not been observed previously in bovine fluorosis. Dark furrows and enamel defects appeared in the teeth of the heifers and the cows. In the skeleton they had osteosclerosis and in some cases also subperiosteal bone appositions. The fluorine content of the skeleton varied between 500 and 3,100 p.p.m. in bone ash. Water samples contained $0.5-2.0$ and the mineral supply $500-630$ p.p.m. of fluorine.

In material from company B widespread enamel defects, strong wear of the deciduous incisors and deviations and irregular eruption of the permanent incisors were found. In the skeleton osteosclerosis and subperiosteal bone apposition and in the kidneys in 1 case patchy atrophy of the tubules were found. Microscopically the skeleton showed signs of repair. The fluorine content of the skeleton varied between 135 and 300 p.p.m. in the ash. In water samples 1.54.0 p.p.m. of fluorine were found. The used mineral supply contained $300-500$ p.p.m. of fluorine. The fluorosis in these animals was considered to be caused by a combination of the fluorine of the water and the mineral supplement. Considering the microscopic picture and the low skeletal fluorine level, the lesions in the bull-calves of company $\mathrm{B}$ were interpreted as fluorosis being in a process of repair. To this view contributed the fact that the ingested fluorine in these animals was reduced during the fattening period.

\section{SAMMANFATTNING \\ Fluoros hos nötkreatur i Sverige.}

Kroniska fluorskador har studerats på kor och kalvar av SRB-ras på gårdar tillhörande 2 lantbruksbolag. Från det ena lantbruksbolaget (HP), beläget i Dalarna, undersöktes 3 kalvar, 4 kvigor och 2 kor och från det andra (B) i Södermanland 12 kastrerade tjurkalvar. Det insända materialet utgjordes dels av ett helt kadaver, insänt för obduktion, dels av huvud, skenben och i en del fall njurar från slaktade djur. Foder- och vattenprover undersöktas på förekomst av fluor. I materialet från HP påvisades utbredda emaljdefekter samt ökad nedslitning i kalvarnas mjölktänder. Fluorotiska tandförändringar hos kalvar är icke kända enligt tidigare undersökningar. En kalv hade 
höggradig osteoporos och de övriga osteoskleros samt subperiostala bennybildningar. I njurarna påvisades i 2 fall härdformig atrofi av tubuli. Njurskador är icke tidigare beskrivna vid fluoros hos nötkreatur. Hos kvigorna och korna påvisades mörka fåror och emaljdefekter i incisiverna. I skelettet förelåg osteoskleros och i några av fallen även subperiostala bennybildningar. Fluorhalterna i skelettet varierada mellan 500-3.100 p.p.m., i askan. Vattenprover innehöll 0,5-2,0 p.p.m. fluor. Det använda mineralfodret innehöll 500-630 p.p.m. fluor.

I djurmaterial från lantbruksbolaget $\mathrm{B}$ påvisades utbredda emaljdefekter, höggradig nedslitning av incisiverna (mjölktänder) samt deviationer och oregelbunden framkomst av de permanenta incisiverna. I skelettet påvisades osteoskleros och subperiostala bennybildningar och i njurarna i ett fall härdformig atrofi av tubuli. Mikroskopiskt påvisades avläkningsbilder i skelettet. Fluorvärdena i skelettet varierade mellan $135-300$ p.p.m. i askan. I vattenprover påvisades $1,5-4,0$ p.p.m. fluor.

Fluorskadorna på dessa båda gårdar ansågs vara orsakade av en kombination av fluorhalten i vattnet och i mineralfodret. Hos tjurkalvarna tillhörande lantbruksbolaget $\mathrm{B}$ ansågs skadorna vara stadda i avläkning på grund av skelettförändringarnas utseende och den låga fluorhalten i skelettet. Detta styrks också av, att mineralfodret ej tillfördes under gödningen, varigenom den intagna fluormängden minskat.

(Received March 23, 1970). 